Maurer School of Law: Indiana University Digital Repository@Maurer Law

1975

\title{
Industrial Deconcentration and Legal Feasibility: The Efficiencies Defense
}

Joseph F. Brodley

Indiana University School of Law

Follow this and additional works at: http://www.repository.law.indiana.edu/facpub

Part of the Industrial Organization Commons, and the Law and Economics Commons

\section{Recommended Citation}

Brodley, Joseph F., "Industrial Deconcentration and Legal Feasibility: The Efficiencies Defense" (1975). Articles by Maurer Faculty. 2505.

http://www.repository.law.indiana.edu/facpub/2505 


\title{
Industrial Deconcentration and Legal Feasibility: The Efficiencies Defense
}

\author{
Joseph F. Brodley
}

The objective of the industrial reorganization bill embodies an ancient and deeply held American value, confinement of discretionary power. In the post-Watergate era there is a resurgence of that ideal, which perhaps may encompass not only governmental power but also the institutions of private economic power. Blocking this path there lies a formidable intellectual barrier: the fear that deconcentration can be accomplished only at grave cost to our productive efficiency. In times of economic recession, perhaps in any times, this seems too high a price to pay. The issue this poses for the industrial reorganization bill is whether it is possible to devise an effective piece of judicial machinery that will stop short of destroying productive efficiencies and yet will go far enough to achieve significant deconcentration. The subject of this article is an attempted answer to that question. I begin with a brief inquiry into what we mean by legal feasibility.

\section{The Nature of Legal Feasibility}

There are severe limits upon what can be managed effectively in a courtroom or before an administrative agency. It is much less than what

The author is Professor of Law, Indiana University, Bloomington. This article was presented at the Annual Meeting of the Association for Evolutionary Economics, San Francisco, California, 27-29 December 1974. The article benefited greatly from the skillful research of Ronald Oakes, a third year student at Indiana University School of Law, particularly as concerns the Public Utility Holding Company Act. 
can be handled in a scholarly inquiry or a closed door study by a panel of experts. Most essentially, this is because the effect of the legal process on a contested factual inquiry is similar to the application of a magnifying glass of high focal power. Issues spring up where they seem not to have existed; simple questions are transformed into matters of high complexity; and that which begins as complex is apt to become wholly unmanageable. All of this takes place in a verbal battle, one level removed from the facts under examination. The flavor was captured thirty years ago by Walton Hamilton and Irene Till in their description of an antitrust proceeding:

\begin{abstract}
Every move, every witness, every fact, every document becomes a counter in a legal game. "The record" has come to do vicarious duty for an analysis of the industry in operation; and every item, favorable to one side, can win admission only against the heavy cross-fire of the other. Every procedural device which may arrest or speed action, flank or snipe the verbal minions of the enemy, color the conduct on parade with innocence or guilt, is called into play. The campaign is lost in its events. ${ }^{1}$
\end{abstract}

The problem is inescapable because the primary standard of procedural justice in a contested legal proceeding is not the efficiency of the procedures but the protection of the rights of litigants. Short of drastically truncating those rights, the only solution is to carefully shape the issues submitted to litigation such that they emerge in clearly articulated, simplified form.

This principle can be seen clearly at work in antitrust law. The success of that law is virtually coextensive with the operation of its simplified, per se rules, such as the rules against price fixing, division of the market between competitors, and horizontal mergers. Where complex rules have been employed, such as the Rule of Reason and in the rules governing remedial aspects of monopolization cases in the last thirty years, the result has been dismal failure.

\title{
Reducing Decisional Complexity
}

Since it will be my conclusion that it is not feasible to eliminate entirely from a deconcentration proceeding the highly complex issue of an efficiencies defense, I am concerned that there are additional complexities that may engulf the proceedings. As matters now stand there are at least seven complex issues to be resolved in a reorganization proceeding, which is roughly five too many. The result is likely to be the draining of 
vital energies from the crucial issue of efficiencies, resolution of which will control effective implementation of the act.

While outside the scope of my article, I tentatively will indicate how these other decisional complexities might be reduced. First, in place of the present three-part test, a single test for monopoly power should be substituted: whether four or less firms account for 50 percent or more of sales. This would delete the two more elusive alternative tests based on high profits and absence of substantial price competition. Second, the new single test would be conclusive rather than merely presumptive of monopoly power. This removes a potentially troublesome Sherman Act inquiry as to whether the four or less firms identified as holding 50 percent or more of the market do in fact possess "monopoly power." Third, administration of the patent defense should be shaped to prevent submersion of the proceedings in a bog of patent invalidity and patent misuse claims. One approach to this defense, which permits monopoly power to be retained if resting solely on valid patents not misused, might be to assume the validity of any patents not previously declared invalid and to require the patent misuse to be flagrant.

\section{The Efficiencies Defense}

\section{The Lessons of the Past}

The draftsmen of the industrial reorganization bill did not attempt to write on a clean slate. In providing for the defense of loss of substantial economies they engrafted the concept and the very language of the Public Utility Holding Company Act of 1935 . Moreover, the issue of loss of economies also has arisen from time to time under the antitrust laws. What lessons does this past history have to teach us?

Protection of Creditors and Investors. Divestiture under the Public Utility Holding Company Act required the reorganization of literally billions of dollars of assets in the form of notes, debentures (secured and unsecured), preferred stock, common stock (voting and nonvoting), and warrants, held at various levels of multitiered holding company structures. The complexity staggered the imagination. In the case of secured instruments the very properties upon which the securities rested often had to be divided. Yet the Securities and Exchange Commission, which was charged with administering the act, was able to preserve the relative value of the various securities to a remarkable degree. ${ }^{2}$ The SEC was given substantially the full discretionary powers of a court of equity, and at least under these circumstances the lesson from the past is one of striking success. 
Viability of Divested Parts. That assets or companies divested shall be able to survive as going concerns is, of course, a minimal condition for divestiture feasibility. So far as I have been able to discover, this condition has been met in divestments under the Public Utility Holding Company Act. Indeed, the commission several times denied divestiture when it hạd serious doubts as to the ability of the isolated system to survive. Surprisingly, in divestitures under the antitrust laws the separated parts often have failed. This has occurred in instances where there has been a sale of assets or companies to outsiders. An example under Section 2 of the Sherman Act was the courtdecreed sale by the old glucose monopoly of plants which were soon thereafter in bankruptcy. ${ }^{3}$ Similar results have been encountered in Section 7 merger relief, where two recent studies have shown a truly remarkable degree of failures in viability. ${ }^{4}$

Fortunately, the solution to the problem seems to be largely a matter of corporate mechanics. When particular assets or companies are required to be disposed of to outsiders, the original corporation and its management have no continuing interest in the success of the disgorged parts. Indeed, they have an opposite incentive; they wish to retain as much as they can of what is valuable and to ensure that the divested parts do not compete with excessive vigor.

On the other hand, if the corporate mechanics are handled so as to give the old shareholders and their officers a continuing interest in the success of the divested assets, the incentives change, and the problem is avoided. This can be done through a distribution of ownership shares in the divested assets to the existing shareholders pro rata in exchange for their old shares. The desired incentive is strengthened, and the problem of continuing control eliminated, if officers, directors, and large shareholders are permitted to hold shares in only one of the new companies, the precise company to be selected by lottery after distribution. ${ }^{5}$

SUbSTANTIAL EFficiencies UNDER THE Utilities Holding COMPANY ACT. The standard of loss of substantial efficiencies was written into the very language of the Public Utilities Holding Company Act. It was crucial to the passage of the act, a key compromise between those who wished to pursue divestiture at whatever cost and those who sought to modify the impact of the law by making divestiture a matter of administrative discretion. ${ }^{6}$ As passed, the act provided that a public utility holding company would be limited to a single integrated system except in those cases where an additional system could not be operated independently "without the loss of substantial economies."”

The issue frequently was litigated as holding companies made repeated attempts to justify retention of one or more additional systems. A 
study of this litigation provides less guidance than one might anticipate for an effective, even handed application of an economies defense. To some extent the statement seems justified that the SEC circumvented the defense.

To begin with, the SEC often was able to bypass the issue of economies by deciding the case on an alternative basis. This was because, unlike the provision in the proposed deconcentration statute, loss of substantial economies was not in itself sufficient to save a system from divestiture; two other conditions also had to be satisfied: geographic contiguity and preservation of the benefits of local management. ${ }^{8}$ If either of these conditions were not met, the economies issue could be, and frequently was, avoided as unnecessary to decision.

Nevertheless, my research assistant, who spent over 100 hours studying the Utility Act decisions, discovered no less than 22 cases in which the economies issue was resolved, although the depth and degree of the analysis varied greatly. Indeed, these decisions reveal that, from the beginning, the SEC adopted a very restrictive view of the economies defense. Defendants were required to prove the existence of substantial economies, not by the usual preponderance of the evidence, but by clear and convincing evidence. ${ }^{9}$ Applying this stringent standard, the SEC developed a series of hurdles which, despite growing sophistication on the part of defendants, proved impossible to surmount except in one very narrow class of cases (discussed below).

In rejecting proferred showings of economies, the SEC offered five reasons, which the courts generally sustained. First, the general quality of the evidence was defective, as based on incomplete data, or not based on the estimates of unbiased observers, or not sufficiently quantified. ${ }^{10}$ Second, some particular error in the evidence was discovered, for which reason the entire offering must be rejected (rather than revised to correct the error). A striking example of this occurred in the New England Electric case, where an entire cost estimate by an independent consulting firm was rejected due to a single error. ${ }^{11}$ Third, the economies were found not to be of the kind protected by the statute, such as loss of ability by the principal system to borrow cheaply from the subsidiary. ${ }^{12}$ Fourth, the economies were not operational economies, such as financial know-how (which could be learned), or tax advantages (which were deemed fortuitous and a function of the changing state of the tax law).$^{13}$ Finally, in the case of combination gas and electric companies, any economies, including convenience to consumers in joint operation, were outweighed by the (unqualified) benefits of competition. ${ }^{14}$

The net result of all this, not surprisingly, was that in scarcely any instance was the economies defense sustained. The only exceptions oc- 
curred in a few cases involving very small companies, where the SEC was persuaded that the additional system would not be able to survive as a separate unit. $^{15}$ In other situations, whatever the showing of economies, the loss was inevitably deemed not "substantial." This result was reached out of hand when the magnitude of the economies amounted to 3 percent or less of operating costs. But the economies defense was also rejected in cases, relatively few, where increased operating expenses of 7,9 , and even 21 percent were projected, with diminutions in net income of 30 percent or more. ${ }^{16}$

Despite the persistently negative ultimate findings, the decisions reveal that there were some economies which the SEC was willing to take more seriously than others. This permits a brief summary to be made of the kinds of proof of economies that stood the best chance of success before the SEC. A strong economies case would (1) rest on the separate findings of two or more teams of independent experts, (2) rely on economies of joint usage of personnel and property, (3) emphasize operations closely coordinated by a centralized management, (4) utilize operating expense projections made on almost every conceivable assumption, and (5) weigh such projections pessimistically as to the results of continued joint operation and optimistically as to the benefits of separate operation.

Administration of the Public Utility Holding Company Act may be instructive in several ways, but one insight it suggests is that an effective means of dealing with an issue of high complexity, here the economies defense, is to all but read it out of the statute. Indeed, the very same tactic seems to have been followed by the Federal Trade Commission in its administration of the cost justification defense to the Robinson-Patman price discrimination law. ${ }^{17}$

Efficiencies in Antitrust Cases. The treatment of efficiencies in antitrust cases has, if anything, been even more cavalier. Occasionally the issue has been raised that a merger be allowed (or, more surprisingly, disallowed) because it would promote efficiencies. But the usual disposition has been that efficiencies are not relevant. ${ }^{18}$

The issue also arises in Section 2 monopoly cases, particularly on the question of relief. Thus, in Second Alcoa Judge Knox declines to order divestiture of Alcoa in part because of the possibility of a "marked loss of efficiency." 19 But other than the finding that there was only one properly located alumina plant, his conclusions are more assumed than proved. In the United Shoe decision, the impracticability of dividing a single manufacturing plant, including its single research facility, again serves as a key reason for denying divestiture relief. ${ }^{20}$ The court men- 
tions, but does not analyze, the underlying problem of allocating managerial and labor personnel between newly created plants.

The United Shoe decision is more instructive in its consideration of the defendant's claim to research superiority. This type of efficiency was not raised, so far as I can ascertain, in the decisions under the Public Utility Holding Company Act. But it seems bound to become a major line of defense under the industrial reorganization bill. The defendant in United Shoe offered evidence which the court accepted as "fully qualified, disinterested and able" that United simply had no equal in the development of machines involving "complex motions in small space." And the court itself characterized United's research organization as having demonstrated "efficiency, intelligence and vision." Nevertheless, the claim to superior efficiency was rejected because the rate of improvement of old machines and invention of new ones did not appear to the court, or to United's chief competitor, whose testimony the court cites, as creating a "formidable record" or justifying "special encomia." ${ }^{21}$ Perhaps inevitably, the decision appears subjective. This may explain the court's unwillingness to countenance division of the research facility. It also reveals the difficulty of litigating an issue of dynamic efficiency.

Were EfFiciencies IN FACT Lost? Notwithstanding the lack of development of feasible legal rules by which to handle determination of efficiencies, it is pertinent to ask whether in fact divestiture has been carried out without loss of serious efficiencies. Such evidence as is available would suggest that no serious efficiency loss has occurred. In the case of the public utility holding company divestitures, it has even been suggested that the breaking up of the holding companies was a positive force for economic health, a "death sentence" only for "a disembodied legal fiction ... a new lease on life for the . . investor." ${ }^{22}$ Nor are any serious efficiency losses to be detected in terms of loss of investment values in early Section 2 Sherman Act divestitures such as the Standard Oil, Tobacco, or Powder Trust divestitures, ${ }^{23}$ or in a series of more recent antitrust spin-offs. ${ }^{24}$

The lesson that can be drawn from this is limited. Divestitures under the Public Utility Holding Company Act followed the exposure of widespread management abuse and were themselves a visible demonstration that needed reforms were being accomplished, helping to restore investor confidence. Moreover, the securities market placed a discount on the indirect ownership of operating companies, which divorcement removed. ${ }^{25}$ Finally, to the extent any inefficiencies were introduced by the breakups, these were ameliorated by the fact that the operating companies were regulated monopolies, utilizing a cost plus method of pricing at 
a time when the efficiency of the whole technology of power generation was rising.

As for the Sherman Act cases, the divestitures under Section 2 typically did no more than replace single firm monopoly with highly concentrated oligopoly; hence these cases really do not approach the issue under the Hart bill. Spin-off of a previously independent company, illegally acquired, similarly fails to answer the question which the division of going concerns would raise.

The short of the matter is that the past history of proceedings under the Public Utility Holding Company Act and under the antitrust laws supplies scant illumination for the path to a feasible economies defense.

\section{Economic Tests for Efficiencies}

Turning from the dusty records of past judicial proceedings, it remains to consider what light economic science can cast upon the problem of ascertaining efficiencies. Legal development often, and not always to its disadvantage, has followed advances in economics. Yet, as suggested earlier, the legal process places a severe constraint on the use of economic analysis: The analysis must be capable of reduction into a comparatively simple, two-valued rule. The legal rule must pronounce that "substantial efficiencies" are either present or that they are not.

Unfortunately, my brief review of the economics of efficiency determination has not led to the discovery of an economic test that is capable of reduction to the simple scope of a workable legal rule which will be dispositive of the efficiencies issue. Perhaps I should make a little more explicit my reading of the economic literature. First, I find a fairly general agreement that plant economies are exhausted at relatively small scale. The situation is less clear as to firm economies, both in terms of their existence and their social desirability. ${ }^{26}$ Second, while there are various tests for ascertaining economies, both plant and firm, none is really suitable for judicial use. The test that comes closest as suitable for a judicial proceeding is the survivor test, under which minimum efficient scale firm is determined by observing the minimum size firm within a defined market that has been able to survive and grow. However, the literature advises that in the view of some economists, at least, there are serious problems with this test, for example, it sometimes leads to seemingly bizarre results as when the smallest and largest firms "survive." 27

The other tests for efficiencies, engineering, statistical, and profit, are each more complex than the survivor test, entailing difficult and highly debatable engineering and accounting judgments. Application of any one of the tests could increase the complexity of a legal proceeding by 
one or more orders of magnitude. Yet, the best results are obtained, I gather, when not one but several tests for efficiency are employed together. As if all this were not enough, there are both static and dynamic efficiencies to be considered. There is X-efficiency, learning effects efficiency, and research and innovative efficiencies (although some of these concepts are perhaps already incorporated in the standard tests) ${ }^{28}$

I conclude that the economic tests are not suitable singly or in a group for blanket incorporation into the deconcentration statute, but properly hedged and restricted, as outlined below, may provide some guidance.

\section{Alternative Legal Approaches to Efficiencies}

Chastened by the limited guidance that is to be drawn from past legal history and economic science, it is my task now to suggest how the issue of economic efficiencies feasibly can be managed in a deconcentration proceeding. There seem to be four possible approaches: (1) Strike the defense from the proposed statute; (2) sustain the defense where there is proof of any significant efficiency loss; (3) sustain the defense only when the efficiency loss is not outweighed by the competitive gain; and (4) sustain the defense, as the proposed bill now would do, only where the efficiency loss is serious or substantial.

The second and third possibilities can be eliminated quickly. To permit the defense on proof of any significant efficiency loss would make the act a dead letter. As experience under the Public Utility Holding Company Act shows, it was a poor management that could not point to some kind of efficiency loss in the separation of even the most isolated utility system.

To require, as would the third possibility, a weighing of efficiency loss as against competitive gain is to compare the obscure with the inscrutible. This was amply demonstrated in the instance of the Public Utility Holding Company Act where such consideration was sometimes attempted. It simply was not done in any rational manner, and it could not be done. The same inability to measure the future competitive impact of new organizational entities caused courts over a decade ago wisely to remove from merger litigation any assessment of the future competitive effects of a merger - a key step in the success of that law.

We must take the first possibility much more seriously. If we, as Frank Kottke recently has urged, ${ }^{29}$ drop the efficiencies defense from the proposed statute, no other single step would do as much to make the act administratively feasible. Nevertheless, this alternative also must be rejected, for two reasons. First, the cost of making the bill legally feasible 
in this manner would destroy its political feasibility. It would be pointed out that abuses of economic power already are sanctioned under the antitrust laws, including Section 2 of the Sherman Act. Thus, the necessary thrust of the industrial reorganization bill would be against the existence of power unaccompanied by abuse and without regard to possible consumer detriment. The symbol of economic power does not sufficiently arouse the public mind for such a step. After all, serious concern about the powers of the so-called Imperial Presidency only developed after the worst abuses in the history of the Republic. In the Public Utility Holding Company Act, passed in response to a record of flagrant abuse by holding companies, it was still found necessary to include an efficiencies defense. Perhaps the situation has been best summarized by the British author A.D. Neale, who observed that Americans have a tendency "to take a romantic view of the achievements and efficiency of large industrial organizations even while they take a suspicious view of their power." 30 An efficiencies defense nicely responds to that bifurcation.

The second reason for not removing the efficiencies defense is the risk that there would be a serious loss in investment values following the passage of the act without such a defense. Investors in concentrated industries in effect would be told that the companies in which they were invested would be broken up regardless of cost. Presumably they made their investments because they believed these firms to be superior in some sense. Many are apt to believe, correctly or incorrectly, that such superiority rested at least in part on market size. A law which proceeded in complete disregard of that factor could seriously undermine investor confidence and hence the value of holdings.

Thus, I conclude that an efficiencies defense very much along the lines of the language now in the proposed statute is necessary. It remains to suggest how it can be implemented in a way that is legally feasible.

\section{Developing a Set of Constraints}

I propose to approach the question of how to implement the efficiencies defense indirectly. Rather than attempt to develop outright a suggested procedure for determining efficiencies, I wish to ask whether it is possible to first formulate a series of complaints which effectively would limit and guide the efficiencies defense. I am impelled to this decision because of the inconclusiveness of any effort to set forth the expected costs and benefits of a deconcentration program. The only certain costs are the transaction costs involved in the protracted proceedings, attorney and expert economist fees, lost executive time, and reorganization costs. 
The only certain benefit is a reduction to some unspecified extent in centralized economic power. All else is shrouded in unascertained probabilities: the loss or increase in the value of output, the impact on business incentive, and the redistribution of political power. In short, the net gain or loss depends upon uncertain probability estimates multiplied by highly subjective payoff values.

Let us turn from this inconclusive vector of forces to consider the impact of deconcentration on those I would call the morally blameless bystanders. These are persons who have made commitments based on the existing scheme, but who are not responsible for it; they may be shareholders, creditors, employees, geographic communities, and perhaps in some sense society as a whole in its reliance on private firms for invention and innovation. Should not the rights of these bystanders impose a constraint on deconcentration policy? One response no doubt will be that there are others, such as consumers, who are equally morally blameless, who have been injured and will continue to be injured unless centers of monopoly power are broken up; these others may in some cases be poorer than the individuals I have referred to. While I concede the persuasiveness of the argument, I deny its implication.

There is a deep-seated policy in our law favoring the protection of vested rights. Such a policy could be said to perpetuate injustice since many vested rights have a tainted foundation. Yet the theory of such protection is that it gives a security to the structure of society's entitlements, which enhance the welfare of all, since without such security no one could be sure that the entitlements he enjoys today would be secure tomorrow. Orderly planning and enjoyment of what one has would be impossible, as all constantly would be in jeopardy.

If you have agreed thus far, you still may ask: But are the groups enumerated morally blameless, particularly shareholders? Are they not the beneficiaries of monopoly power? I shall argue that for the most part they are not. Given the typical, long sustained oligopoly condition, most of the shareholders, creditors, and employees will have made their commitments long after market power was acquired. As a result, their return on their investment or job is apt to be no greater than those who have committed to more competitive industries. Thus, they not only have no responsibility for the concentrated market condition, but also are not even benefiting from it. They are esentially in the same position as those who have committed to more competitive sectors.

This is not to defeat the idea of deconcentration, but to place a constraint upon how it is to be accomplished. Consideration of the rights of morally innocent bystanders can be accomplished by imposing on the industrial deconcentration program several constraints. (1) The total ef- 
fect of deconcentration should impose no confiscatory loss on investors (shareholders or creditors). (2) The immediate effect should impose no severe fluctuation in values for investors. (3) No serious innovative loss should be inflicted. (4) No severe loss of employment should result. (5) No severe disruptions should be caused to geographic communities.

The relation of the efficiencies defense to these constraints is clear. A severe loss of efficiencies is apt to impose some or all of the losses enumerated above. And the losses would be no less because they stemmed from impairment of firm efficiencies rather than plant efficiencies, hence both types of efficiencies should be recognized. The constraints also have implications for the type of relief to be imposed. Radical surgery, such as the closing on short notice of plants or units, could severely disrupt smaller communities and employment. It also could cause large fluctuations in securities values, which would become permanent losses for those who must surrender their commitments during the short period.

The thrust of all of this is toward gradualism in adjudging relief and toward voluntarily conceived plans. These considerations frequently will militate in favor of relief centered on lowering of entry barriers, aimed at achieving deconcentration over a longer time frame. Yet immediate and direct divestiture is not by any means ruled out.

\section{Formulating a Specific Approach}

With these constraints in mind and in light of the legal history and economic views discussed, is it now possible to consider a more specific approach to the handling of the efficiencies defense? Essentially I shall suggest a three-stage procedure.

Step 1 would be to designate what I shall call a dissolution target. This would consist of the minimum deconcentration necessary to achieve a market structure that is workably competitive. Definitions as to what is workably competitive no doubt will vary, but I would define this as a market structure free of highly concentrated oligopoly and in which there are several innovative centers. A typical dissolution target might be a minimum of twelve firms in the market, with no firm larger than 10 percent. This is to be contrasted with the language in the present bill, which calls on the commission to determine "the maximum feasible number of competitors ... without the loss of substantial economies." Such a determination would become redundant under the approạch I am suggesting, for it would point to more deconcentration than would be required.

Stage 2 would involve the tentative confirmation of the dissolution 
target by utilizing the only economic test which is at all amenable to simple application, the survivor test. Under this test the dissolution target would be confirmed if firms of the proposed deconcentrated scale have been able to survive and grow in the market. If there is insufficient experience or data in the domestic market, recourse might be made to foreign markets in competition with U.S. markets. Confirmation of the dissolution target by the survivor test would lead to a strong presumption that deconcentration would entail no loss of substantial economies.

In the third stage, defendants would be given the opportunity by any means they think appropriate to prove loss of substantial economies. Here the demanding qualitative standard on proof of efficiencies imposed by the SEC under the Public Utilities Holding Company Act is worthy of some emulation; thus, the insistence on thoroughly grounded projections by independent experts is a sound requirement. On the other hand, care must be taken not to go so far as did the SEC in undermining the efficiencies defense, for that would defeat the suggested constraints and their underlying values. To prevent this and to ensure that the defense retains substance, it would be desirable to establish, by statute or by guideline, a definite numerical measure of what constitutes substantial economies. Tentatively, I would suggest the figures of a 5 percent or greater increase in total costs, or a 25 percent reduction in net profit after taxes, either of which would be sufficient to sustain the defense.

I would fully expect that this standard might be met and the defense sustained in some cases, particularly given the slippage in the litigation machinery. But I would not fret over this; indeed, in some ways I would welcome it. For it would serve to reassure the public that real economies were not being sacrificed in the deconcentration program, and I would hope that this would help to steady investment values in those deconcentrations that were ordered.

Moreover, and this point bears emphasis, the sustaining of an economies defense would not terminate the deconcentration proceeding. On the contrary, it might help pave the way for the alternative remedy, the lowering of entry barriers, for the efficiencies defense will require the firm to demonstrate with some precision the particular efficiencies or methods that enable it to enjoy lower costs or higher profits. Such a demonstration may provide precisely the information the commission needs to determine the relief necessary to lower entry barriers. Entry barrier relief necessarily will be slower than divestiture, but that very gradualness is exactly what is desired under the criteria I have urged, when substantial economies are involved.

Certain procedural devices would be desirable to shorten and simplify 
the complex proceeding that an efficiencies defense, whatever its form, entails. Such devices, many of which have been used in past protracted litigations, might include filing in advance of the hearing all direct testimony in narrative form and exhibits, exchanging objections to testimony and exhibits and rulings thereon in advance of the hearing, confining the actual hearing to cross examination, greater use of court-appointed witnesses, and possibly the use of expert masters to determine technical questions of engineering and cost accounting.

\section{Conclusion}

The industrial reorganization bill can be made legally feasible. Some of its decisional complexity can be removed without injury to its basic object, the limitation of economic power. The difficult issue of efficiencies remains, but a legally feasible way of handling this issue seems possible. According fair recognition to the defense and avoiding the stringency that was imposed on the similar defense in the administration of the Public Utility Holding Company Act are apt to bar some divestitures, but in those cases relief could then proceed by the more gradual method of removing entry barriers. Even in those instances where no effective relief at all results, there is value in the proceedings, for they require concentrated economic power to account for its stewardship and to demonstrate that the continuance of such power serves the public interest. At least once in a generation that is a healthy posture for those who hold great power, economic or any other kind.

Of course, there are risks, and these have been expressed with determination by a distinguished spokesman: "The drafters of this bill are self-proclaimed disciples of the social theory that American corporations are too large, and consequently their operations should be divided into small pieces. ... Suffice to say ... that ... the application of such a theory to American business in whole or in part will result in a financial and economic chaos compared to which the present economic condition will look like prosperity." 31 Perhaps such fears are exaggerated, for that was a speech delivered by Wendell Wilkie in opposition to the Public Utility Holding Company Act of 1935.

\section{Notes}

1. Walton Hamilton and Irene Till, "Antitrust in Action," TNEC Monograph No. 16 (1941), p. 60.

2. R. Blair-Smith and L. Helfenstein, "A Death Sentence or a New Lease on Life," 94 University of Pennsylvania Law Review 148 (1945). See 
also Comment, "Section 11(b) of the Holding Company Act: Fifteen Years in Retrospect," 59 Yale Law Journal 1088 (1950).

3. George Hale, "Trust Dissolution: 'Atomizing' Business Units of Monopolistic Size," 40 Columbia Law Review 615 (1940).

4. P. Elinza, "The Antimerger Laws: Pyrrhic Victories?" 12 Journal of Law and Economics 43 (1969); Pfunder, Plaine, and Whittemore, "Compliance with Divestiture Orders Under Section 7 of the Clayton Act: An Analysis of the Relief Obtained," 17 Antitrust Bulletin 19 (1972).

5. See W. L. Baldwin, "Selective Divestiture by Spin-Off and Lottery: A Modest Proposal," 6 Antitrust Law and Economics Review 107 (Winter 1972-1973).

6. See R. Ritchie, Integration of Public Utility Holding Companies (Ann Arbor: University of Michigan Law School, 1954); and SEC v. New England Electric System, 384 U.S. 176, 189-90 (1966) (Harlan and Stewart, J.J., dissenting).

7. 15 U.S.C.A. $\$ 79 \mathrm{k}(\mathrm{b})(1)(\mathrm{A})$.

8. See, for example, Cities Service Power \& Light Co., 14 S.E.C. 28, 37 (1943): "[T]he (A) (B) (C) standards are cumulative. All must be satisfied before retention may be permitted."

9. Ritchie, Integration, p. 187.

10. For example, American Gas \& Electric Co., 21 S.E.C. 575 (1945).

11. New England Electric System v. SEC, 390 U.S. 208 (1968), reversing 376 F.2d 107 (1st Cir.), on remand from 384 U.S. 176, reversing and remanding 346 F.2d 399 (1st Cir.), reversing 41 S.E.C. 888 (1964).

12. North American Co., 11 S.E.C. 194 (1942).

13. For example, Cities Service Co., 15 S.E.C. 962 (1944), and North American Co., 11 S.E.C. 194 (1942).

14. For example, Engineers Public Service Co. v. SEC, 138 F.2d 936 (D.C. Cir. 1943) affirming in part, reversing in part, 12 S.E.C. 41 (1942).

15. Engineers Public Service Co. v. SEC, 138 F.2d 936 (D.C. Cir. 1943); North American Co. v. SEC, 133 F.2d 148 (2d Cir. 1943), affirming 11 S.E.C. 194 (1942); Columbia Gas \& Electric Co., 17 S.E.C. 494 (1944); Cities Service Power \& Light Co., 15 S.E.C. 675 (1943); and Republic Electric Power Corp., 3 S.E.C. 992 (1938).

16. See the summary tables prepared by the SEC and the appellate court, presented in the New England Electric System litigation, 41 S.E.C. 888, 905 (1964) and 376 F.2d 107, 117 (1st Cir. 1967), and the table prepared by Ritchie in Integration, at p. 186.

17. Ralph Fuchs, "The Requirement of Exactness in the Justification of Price and Service Differentials Under the Robinson-Patman Act," 30 Texas Law Review 1, pp. 18-19 (1951).

18. For example, Federal Trade Commission v. Proctor \& Gamble Co., 386 U.S. 568 (1967).

19. United States v. Aluminum Company of America, 91 F. Supp. 333, 416 (S.D.N.Y. 1950).

20. United States v. United Shoe Machinery Corp., 110 F. Supp. 295 (D. Mass. 1953).

21. Ibid., pp. 330-31.

22. Blair-Smith and Helfenstein, "Death Sentence," p. 148. 
23. Hale, "Trust Dissolution."

24. Statement of Donald E. Weeden in The Industrial Reorganization Act, Antitrust \& Monopoly Subcommittee of Senate Judiciary Committee, Hearings on S. 1167 (93d Cong., 2d sess.), Part 3, p. 2152 (1974).

25. Blair-Smith and Helfenstein, "Death Sentence," p. 199; and D. Cook and H. Cohn, "Capital Structures of Electric Utilities Under the Public Utility Holding Company Act," 45 Virginia Law Review 981 (1959).

26. See, generally, F. M. Scherer, Industrial Market Structure and Economic Performance (Chicago: Rand McNally \& Co., 1970), chapter 4, pp. 72-103; F. M. Scherer, "Economies of Scale and Industrial Concentration," and John McGee, "Efficiencies and Economies of Size," in Industrial Concentration: The New Learning (Boston: Little Brown \& Co., 1974), pp. 16-113; and F. J. Kottke, "Dissolution and Scale Economies: A Comment," 5 Antitrust Law and Economics Review 55 (Winter 1971-1972).

27. George Stigler, "The Economies of Scale," in The Organization of Industry (Homewood, Ill.: Richard D. Irwin, Inc., 1968), p. 71; T. R. Saving, "Estimation of Optimum Size of Plant by the Survivor Technique," 75 Quarterly Journal of Economics 569 (1961); Leonard Weiss, "The Survival Technique and the Extent of Suboptimal Capacity," 72 Journal of Political Economy 246 (June 1964); and W. G. Shepherd, "What Does the Survivor Technique Show About Economies of Scale?" 34 Southern Economic Journal 113 (July 1967).

28. Aubrey Silberson, "Economies of Scale in Theory and Practice," Economic Journal (March 1972 Supplement), pp. 369, 386-87.

29. See Kottke, "Dissolution." Kottke would permit Congress, as distinct from the courts, to consider efficiencies by adopting special exempting legislation for those particular industries Congress determined would lose efficiencies through divestiture. But Congress would seem ill suited to make that kind of a judgment, requiring lengthy study of highly complex and specific facts. The pull of special interests via ex parte approach would be enormous, which may be one reason Congress has sought to avoid particularization in the antitrust field by passing highly generalized statutes. The contrary example of the Bank Merger Act of 1966, where particular banks were in effect exempted from the mandate of the merger laws, although resting on a plausible procedural argument, appeared to many as invidious and arbitrary.

30. A. D. Neale, The Antitrust Laws of the U.S.A. (London: Cambridge University Press, 1960), p. 436.

31. Wendell L. Wilkie, "The New Fear," an address delivered in Washington, D. C., 1 May 1935. 